\title{
Hitek és tévhitek, azaz vitatott esszenciális kérdések a kézhigiénéről az evidencia tükrében
}

\author{
Szél Borbála ${ }^{1}$ - Nagy Kamilla dr. ${ }^{1}$ - Milassin Márta dr. ${ }^{2}$ - Tálosi Gyula dr. ${ }^{3}$ \\ ${ }^{1}$ Szegedi Tudományegyetem, Szent-Györgyi Albert Klinikai Központ, Kórházhigiénés Osztály, Szeged \\ ${ }^{2}$ Országos Epidemiológiai Központ, Dezinfekciós Osztály, Budapest \\ ${ }^{3}$ Bács-Kiskun Megyei Kórház, Csecsemő- és Gyermekgyógyászat Osztály, Kecskemét
}

\begin{abstract}
Az egészségügyi ellátás során szerzett fertőzések kialakulásában nagymértékben szerepet játszhat a kontaminált kéz. A megfelelő időben és technikával elvégzett kézhigiéné a betegbiztonság elengedhetetlen eszköze, ugyanakkor, ha az egészségügyi dolgozót téves meggyőződései és hiedelmei meggátolják a magas szintű kézhigiénés compliance megvalósításában, akkor ez jelentősen ronthatja a betegellátás minőségét. Számos vélt gondolat és téves tudás befolyásolhatja a dolgozói attitűdöt, és gyakran alaptalan meggyőződések állnak a nem megfelelő kézhigiénés compliance hátterében. Az evidenciák felkutatása, elemzése és közérthető ismertetése rendszeres oktatás és továbbképzés formájában - kiemelve a kézhigiéné elméleti és gyakorlati aspektusait - segíthet elsajátítani és rögzíteni a helyes technikát és az evidencián alapuló ismereteket. Orv. Hetil., 2017, 158(6), 212-219.
\end{abstract}

Kulcsszavak: kézhigiéné, kézhigiénés compliance, alkoholos kézfertőtlenítés, infekciókontroll

\section{Beliefs - Misbeliefs, answering essential questions about hand hygiene from the view of the evidences}

\begin{abstract}
Contaminated hands can play pivotal role in the development and spread of healthcare-associated infections. Consequently hand hygiene practice performed with adequate technique and with adequate timing is an essential implement for patient safety. Inhibition of the practice of high level hand hygiene by the misconceptions or deficient knowledge of healthcare workers may lead to negative influence on the quality of patient care. Erroneous beliefs or "rumourous knowledge" acquired from colleagues can not only influence the attitude of healthcare workers, but can also give rise to insufficient hand hygiene compliance. Finding, interpreting and imparting the related evidence by delivering continuing education and lectures, highlighting the theoretical and practical know-how on hand hygiene could help to understand and imprint the evidence-based practice and adequate technique in the essential issue of hand hygiene.
\end{abstract}

Keywords: hand hygiene, hand hygiene compliance, alcohol-based hand rub, infection control

Szél, B., Nagy, K., Milassin, M., Tálosi, Gy. [Beliefs - Misbeliefs, answering essential questions about hand hygiene from the view of the evidences]. Orv. Hetil., 2017., 158(6), 212-219.

(Beérkezett: 2016. november 3.; elfogadva: 2016. december 1.)

\section{Rövidítések}

$\mathrm{BPA}=$ biszfenol A; KC = kézhigiénés compliance; OEK = Országos Epidemiológiai Központ; WHO = Egészségügyi Világszervezet
Az egészségügyi ellátással összefüggő fertőzések világszerte nagy problémát jelentenek [1], mivel hatalmas terhet rónak mind a megbetegedett személyre, annak családjára, mind a betegellátást nyújtó egészségügyi in- 
tézményekre [2]. A kézhigiéné az egyik legfontosabb eszköze az infekciókontroll-tevékenységnek, amelynek segítségével megakadályozhatók a keresztfertőzések [3], ami az egészségügyi ellátással összefüggő fertőzések közel felének megelőzését jelentené.

Bár a kézhigiéné fontosságára Semmelweis Ignác már az 1800-as évek végétől felhívta a figyelmet, és mára széles körben felismerték, hogy a sebészi kézfertőtlenítés (bemosakodás) mellett a mútőn kívüli sokrétú betegellátás során is megfelelő higiénés kézfertótlenítést kell alkalmazni a kórokozó mikroorganizmusok terjedésének megakadályozásához, mégis az egészségügyi dolgozók kézhigiénés compliance-e világszerte igen alacsony (átlagosan $<40 \%)[4,5]$.

A nemzetközi kézhigiénés kampányok és irányelv [5] megjelenését követve Magyarországon is kiadtak egy módszertani levelet [6], amely rögzítette a betegellátás területén a bemosakodáson kívül alkalmazandó kézhigiéné szabályait és azokat az indikációkat, hogy mikor és hol kell elvégezni azt. Magyarországon a betegellátó intézmények kórház-higiénikusai rendszeresen kötelesek mérni intézményük betegellátóinak higiénés kézfertőtlenítéshez való hozzáállását, azaz a kézhigiénés compliance-t (KC) és az eredményeikról évente tájékoztatniuk is kell az Országos Epidemiológiai Központot (OEK). A KC mérése történhet direkt módon a kézhigiénés tevékenység megfigyelésével, de ami objektív és az országos, illetve a nemzetközi adatokkal is egyszerúen összehasonlítható, az az indirekt vizsgálat. Ennek során az intézmény által felhasznált kézfertőtlenítő szer mennyiségét adjuk meg 1000 ápolási napra vonatkozóan, és ebből kiszámolható az is, hány kézfertótlenítést végeznek az adott betegellátó helyen átlagosan egy betegnél 24 óra alatt (ez az adat nem tartalmazza a sebészi kézfertőtlenítéshez, azaz a mútő́kben a be-, át- és kimosakodáshoz használt kézfertôtlenítő szer mennyiségét) $[5,6]$.

Magyarországon a betegellátó intézmények egymás után csatlakoztak a kézhigiénés kampányokhoz, aminek eredményeként az országos átlagos $\mathrm{KC}$ az elmúlt években jelentősen javult, míg 2011-2012-ben 7 liter/1000 ápolási nap volt, addig 2015-ben már 9,9 liter/1000 ápolási nap. Ugyanakkor a kézhigiénés hozzáállás további fejlődését minden erőfeszítés ellenére lassíthatják bizonyos tényezők, mint például a nemek közötti különbség [7], az orvosok és ápolók közötti különbségek [8], az intenzív osztályon való munkavégzés [9], a munkavégzés hétköznap vagy hétvégén történik [10], valamint a szabályok betartására rendelkezésre álló idő [11]. Sôt a dolgozói kézhigiénét vizsgáló kérdőívek és interjúk a fent felsorolt tényezók mellett gyakran olyan attitúdök megjelenésére is rávilágítanak, amelyek feltehetőleg a nem megfelelő ismeretek talaján alakultak ki. Ezek olyan magatartásformák, amelyeket jól láthatóan nem a fegyelmezetlenség, hanem az ismeretek hiányán alapuló félreértés, tévhit irányít.

Jelen kézirat szerzőinek célja, hogy a higiénés kézfertőtlenítés területén az evidenciák tükrében olyan kulcs- fontosságú kérdéseket tisztázzanak, amelyekkel kapcsolatosan az egészségügyi dolgozók körében féligazságokon vagy félreértésen alapuló tévhitek terjednek, amik akadályozhatják óket abban, hogy a KC-jük az elvártnak megfelelő legyen.

$\mathrm{Az}$ alábbiakban 10 kérdésre kerestük a választ:

\section{Valóban nincs idő a higiénés kézfertőtlenítésre?}

A dolgozók gyakran arra hivatkoznak, hogy nincs idő a kézhigiénére a feszített, stresszes helyzetekben. Az időhiányt az ápolószemélyzet olyan viszonylatban is emlegeti, hogy kevés a betegápoló és sok a beteg, így a teendők sứrújében nincs elég idő minden szükséges esetben a szabályosan kivitelezett kézhigiénére.

A betegellátásban a higiénés kézfertőtlenítés középpontjában az Egészségügyi Világszervezet (WHO) javaslata alapján [4] az alkoholtartalmú kézfertótlenítő szer használata áll.

Az alkoholos kézbedörzsölés módszere során a fertôtlenítőszert eloszlatjuk a kezünkön dörzsölő mozdulatokkal addig, amíg a fertőtlenítőszer kifejti kórokozóölő hatását, majd elpárolog (körülbelül 20-30 másodperc). Ezt a technikát alkalmazzuk a betegellátás során minden olyan esetben, amikor kezünk szemmel láthatóan nem szennyezett, illetve a védókesztyü felvétele előtt és levétele után is.

E legfrissebb kézhigiénés szabályok már tökéletesen illeszkednek az idóhiányhoz, mivel a minimum 2 percig tartó kézmosás helyett a mindössze 20 másodpercig tartó fertőtlenítőszeres kézbedörzsölést ajánlják [6]. Ezt támasztja alá a Voss és mtsai által végzett vizsgálat, amelyben egy intenzív osztályon, ha a kézhigiénét fertótlenítő hatású szappannal végzik, akkor a munkaidő 17\%-át töltik el fertőtlenítő kézmosással, míg ha a kezeket alkoholos kézbedörzsölővel fertőtlenítik, akkor az ugyanannyiszor elvégzett kézhigiénés tevékenység kevesebb, mint 3\%-át teszi ki a munkaidőnek [11]. Ha a dolgozóinkkal ismertetjük a legfrissebb kézhigiénés ajánlásokat és következetesen be is tartják azt, akkor lesz elegendő idejük a szükséges esetekben a kézfertőtlenítésre.

\section{Kiszárítja a kezeket az alkoholos kézfertőtlenítő szer?}

Az egészségügyben a munkavállalónak, ha közvetlenül beteget lát el, kézhigiénét kell alkalmaznia a WHO által kiadott szakmai ajánlásban szereplő öt kézhigiénés momentum szerint: a beteg érintése előtt és után, a váladékkal történő expozíciók után, az aszeptikus beavatkozások előtt és a beteg környezetének érintése után minden esetben [4]. Ha ilyenkor a betegellátó keze szemmel láthatóan nem véres vagy váladékos, alkohol hatóanyagú kézfertőtlenítő szeres bedörzsölést jelent a kézhigiéné.

A betegellátók egy része azonban kerüli a fertőtlenítőszeres kézbedörzsölést, mert azt gondolja, hogy mindegy, milyen kézfertőtlenítő szert kap, mindegyik árt a kézbőrének. 
Ha ugyanakkor a munkáltató is azt gondolja, mindegy, milyen kézfertőtlenítő szert ad a dolgozójának és ezért a legolcsóbbat szerzi be neki, valóban azt fogja látni, hogy a dolgozó kézbőre károsodik. Több tanulmány is igazolja, hogy a kézfertőtlenítő szerek minősége döntően befolyásolja azt, hogy okoz-e a szer bőrkárosodást, kimutatták ugyanis, hogy a károsodást nem maga a hatóanyag okozza, hanem a szerben található adalékanyagok (például színezékek) és szennyeződések. A jó minőségú termékek ezektől mentesek, sőt bőrvédő összetevőt is tartalmaznak $[12,13]$.

Ha a dolgozónak fáj a keze a fertőtlenítőszertől, nem meglepő, ha igyekszik elkerülni annak használatát és például a fertőtlenítőszeres kézbedörzsölés helyett kezet mos.

Ennek a higiénés szabályszegésnek a betegellátás minden résztvevőjére nézve súlyos következményei lehetnek: az ilyen dolgozó kézhigiénéje nem garantálja a betegbiztonságot, mivel a szappanos kézmosás csak csíraszámcsökkentő. A szappanos kézmosás ugyanakkor eltávolítja a kézbőr nedvesítő-zsírzó faktorait, ami már a dolgozói biztonságot is veszélyezteti. Az egészségügyi személyzet leggyakrabban előforduló foglalkozási megbetegedései rangsorában, a mozgásszervi megbetegedések után, valóban a bőr betegségei állnak a második helyen [14]. A foglalkozási bőrbetegségek 80\%-át a kontaktdermatitis teszi ki [15].

A sérült bőrön ráadásul könnyebben megtelepszenek a kórokozók, mint az ép bőrön [16]. Egy, nővérek körében végzett vizsgálat során olyan betegellátók kezét mintázták meg, akiknél már kialakult a dermatitis; a mintákból Staphylococcus hominis, Staphylococcus aureus, Gram-negatív baktériumok, Enterococcusok és Candida is kimutatható volt [17].

A kézfertőtlenítő szerek kiválasztásánál ezért nem az árverseny a helyes megoldás, hanem az egyéni érzékenység figyelembevétele, azaz a dolgozó számára annak a fertőtlenítőszernek a biztosítása, amelyet az ő bőre a legjobban elvisel. Ez az első aranyszabály, amely jelentősen képes javítani annak a dolgozónak a KC-jét, akinek az egészségügyben a betegellátás során a kézfertőtlenítő szert éveken át, folyamatosan és óránként akár többször is rá kell dörzsölnie a saját bőrére [18]. A nagy létszámú dolgozót foglalkoztató intézményekben többféle kézfertôtlenítő szert is javasolt biztosítani, hogy az egyéni érzékenységet is figyelembe véve legyen választási lehetősége a dolgozóknak. Ez a gyakorlatban úgy valósítható meg, hogy a dolgozók által kipróbált és a gyakorlatban már bevált szereket versenyeztetik és ezek közül választják ki az árban is legmegfelelőbbeket. A szakma képviselőinek erre kellene a jövőben bátorítania a menedzsmentet.

\section{Igaz-e, hogy felszívódik a bőrön és a légutakon át a kézfertőtlenítéskor az alkohol, és akár alkohol- abúzus is kialakulhat?}

$\mathrm{Az}$ e területen végzett vizsgálatok semmilyen, vagy alig kimutatható mértékben találtak véralkoholszint-emelke- dést kézfertőtlenítő szer használata következtében, és ezzel kapcsolatos tüneteket sem tudtak feljegyezni [19$21]$.

Egy tanulmányban olvasható, hogy az 52,6\%-os izopropiltartalmú kézfertőtlenítő szer gyakori használata - 4 órán át 10 percenként alkalmazott kézfertőtlenítés után önkéntesek levett vérmintáiban 10 esetből 9-nél 0,005-0,18 $\mathrm{mg} / \mathrm{dl}$ izopropilszint volt kimutatható, ugyanakkor enyhe mértékű izopropilintoxikációhoz legalább $50 \mathrm{mg} / \mathrm{dl}$ véralkoholszint szükséges [20]. Egy 2012-es tanulmány is azt mutatta be, hogy a propanol vegyülete jelentéktelen mértékű felszívódásra képes, akut toxikus tünetet nem tud létrehozni, és mivel az emberi anyagcsere gyorsan feldolgozza, nem tud a vegyület akkumulálódni [21].

Bár Brown és mtsai vizsgálatukban azt találták, ha intenzíven és gyakran végzik az etanoltartalmú kézfertőtlenítő szeres kézbedörzsölést (az említett tanulmányban 1 óra alatt 30 kézfertőtlenítés történt), akkor csekély mennyiségű etanol felszívódhat a bőrön keresztül, illetve egy zárt légterü helyiségben be is lehet lélegezni a kézről elpárolgó alkoholt. Ezek a mennyiségek azonban a közúti ellenőrzésnél alkalmazott alkoholszintmérő szondán nem mutatnak eltérést [19].

Kinnula és mtsai kutatásukban bemutatták, hogy a gél állagú alkoholtartalmú kézfertőtlenítő szer (amely nem szívódik fel a kéz bőréről) használata még az óvodások körében is teljesen veszélytelen, miközben megelőzheti a közösségben gyorsan terjedő vírusok kéz útján való továbbadását [22].

\section{Valóban a kézfertőtlenítés a felelös a szervezet biszfenol A (BPA) -tartalmának esetleges emelke- déséért?}

A legnagyobb mennyiségben elő́llított kémiai anyagok közé tartozik a BPA, és jól ismert egészségkárosító hatása (hormonális zavarok, szívbetegség, asztma, elhízás), azonban az alkoholos kézfertőtlenítők és szappanok kémiai összetevői között nincs BPA.

Az ezzel kapcsolatos tévhit onnan származik, hogy BPA-val vannak bevonva a banki automatákból, pénztárgépekből, faxgépekből, illetve tesztgépek/orvosi analizátorokból származó bizonylatok. Egy 2014 végén publikált cikk [23] arról számolt be, ha a hőpapírra nyomtatott bizonylat megfogása előtt közvetlenül kezet fertőtlenítünk és 45 másodpercen keresztül kezünkben tartjuk a hőpapírt, a kézhigiénés szerekben lévő penetrációt fokozó anyag elősegítheti a BPA ujjainkon való kioldódását, és ha ezzel a kézzel eszünk, annak szájnyálkahártyán keresztül történő felszívódását. Ebből azt a következtetést vonta le néhány közösségi oldal és blog, hogy soha többé ne fertőtlenítsünk kezet. E javaslatok nélkülözik a betegellátás higiénés szabályainak ismeretét, sőt az alapvető személyhigiénés szabályokét is. Bár az evidenciát mellőző internetes reakciók eltorzítják az említett kutatás üzenetét, annyi hasznos információval szolgálhatnak akár egészségügyi dolgozók számára is, hogy a 
hőpapír nyomtatású bizonylatokat feleslegesen nem kell megfogni, a munkahelyen pedig - ha ezzel dolgozik valaki - használjon védőkesztyüt, de a szükséges kézhigiénét semmiképpen se hagyja el.

\section{Először kell kezet mosni és utána fertőtleníteni vagy fordítva? Fontos egyáltalán a kézmosás és a kézfertőtlenítés egymást követő sorrendje?}

Kétféle higiénés kézfertőtlenítés létezik: víz hozzávételével történő fertőtlenítő hatású folyékony szappanos kézmosás és kézfertőtlenítés alkoholbázisú, fertőtlenítő hatású szer kézbőrre történő bedörzsölése útján [4, 24].

Míg az alkoholos kézbedörzsölés célja az úgynevezett átmeneti (tranziens) mikroflóra elpusztítása, a fertőtlenítő hatású folyékony szappanos kézmosás során a készítmények összetételéből adódóan (a készítmények tenzidtartalmának köszönhetően) a tranziens mikroflórán kívül a szennyeződések eltávolítása is megtörténik. Ugyanezt el lehet érni két fázisban is, amikor külön végezzük el a szappanos vizes kézmosást és külön a kézfertőtlenítő szeres kézbedörzsölést a tisztítás és a megfelelő csíraszámcsökkentés érdekében. Ennek a két fázisnak a sorrendje a mindenkor érvényes kézhigiénés szabályokban többször is változott az elmúlt években, ami megnehezíti a kézhigiéné egyes lépéseinek rutinná válását. 1973-ban, amikor még hagyományos szappant használtak a kéz megtisztítására, csak a kétfázisú kézfertőtlenítés jöhetett szóba, ha a kéz tisztítására és fertőtlenítésére is szükség volt. Ekkor az Egészségügyi Minisztérium II. Oktatási Főosztálya az általa kiadott jegyzet (1973, Budapest) „Személyi fertôtlenítés" című részében - azt írta elő, hogy a járványügyi gyakorlatban a kézmosás előtt kell a kézfertőtlenítő szert használni azért, hogy a kórokozók ne kontaminálják a szappant, a kézmosó csapját, a mosdókagylót. Majd a szappanos kézmosás után egy újabb kézfertőtlenítés következzen, amelynek célja, hogy a már megtisztított kezeken esetleg visszamaradó kórokozókat elölje. A sok időt igénylő és bonyolult kézhigiénét egyszerúbbé és logikusabbá tette az Országos Epidemiológiai Központ (OEK) a következő években a betegellátó intézményekben kötelezően alkalmazandó ajánlásában [25-27], amikor azt írta, hogy a kétfázisú higiénés kézfertőtlenítés során először történjen a kézfertőtlenítés alkoholos kézbedörzsölő szerrel, és amit elpusztított a kézfertőtlenítő szer, azt mossuk le utána szappannal és vízzel. Napjainkban már a szilárd szappan alkalmazása az egészségügyben tilos. 2009 óta a WHO kézhigiénés irányelve [4] az alkoholbázisú kézfertőtlenítő szeres kézbedörzsölést önmagában preferálja és csak kivételes esetekben javasolja a szappanos kézmosást is, például, ha szemmel látható mennyiségú szerves anyag (vér, váladék) van a kézen. Ezekben a kivételes esetekben azonban megfordította a fertőtlenítés és a tisztítás sorrendjét, azaz először kell szappannal és vízzel megtisztítani és csak utána fertőtlenítőszerrel bedörzsölni a kezet. A magyarázat ez esetben is logikus, mert a kézfertőtlenítés hatékonysága nem valósítható meg tökéletesen másképpen, a gyorsan párolgó alkoholos kézfertőtle- nítő szer ugyanis el sem tud jutni a kéz bőréhez, ha akadályozza az ott lévő szerves anyag. Ezt az elméletet követi és ezt a sorrendet írja elő már a hazai módszertani levél [6] és az OEK Tájékoztató a fertőtlenitésrőll ötödik kiadása [28] is.

Annak ismeretében, hogy mára már forgalomba kerültek felületfertőtlenítő kendők is, amelyekkel gyorsan és hatékonyan lehet csíramentesen tartani a folyamatosan kontaminálódó kézmosó csapok és mosdókagylók felületét, érthető a WHO új álláspontja, ami nem építi be ezt a szempontot a kézhigiéné lépéseibe. A kézmosó kagyló és a szerelvénye ugyanis a legszennyezettebb része egy betegellátó helynek, ahonnan még akkor is a kézre kerülhetnek kórokozók a víz csapódása miatt, ha a szabályoknak megfelelően könyökkel nyitható csapokat használnak. A kéztisztítás és kézfertőtlenítés ma érvényes sorrendjére vonatkozó szabály betartását segíti, ha a dolgozók számára a kéz tisztításához folyékony szappan helyett fertőtlenítő hatású kéztisztítószert biztosítunk, és akkor indokolt esetben egy fázisban végeztethetjük el a kéz tisztítását és fertőtlenítését is. Így fel sem merülhet a kéztisztítás és a kézfertőtlenítő szeres bedörzsölés sorrendjének kérdése, és az sem fordulhat elő, hogy a hatékony kézhigiéné helyett csak szappanos kézmosást végeznek a betegellátók.

\section{Mikor kell szappannal kezet mosni és mikor kell csak kezet fertőtleníteni?}

A kézmosás szappannal mechanikus kéztisztítást jelent, miközben 0,5-1 percig dörzsöljük rá a folyékony kéztisztítószert a kézre úgy, hogy az a kéz minden területét egyenletesen bevonja - ügyelve a körömágyakra, ujjbegyekre és hüvelykujjakra is [29] -, majd folyó vízzel leöblítjük és alaposan megszárítjuk eldobható papírtörlővel. A szappanos vizes kézmosással azonban nem tudunk elérni megfelelő kórokozószám-csökkenést, még a kézmosás időtartamának növelésével sem [30]. A kéz a nem lengőkaros csap elzárásakor a gomb érintésétől, vagy a vízkedvelő baktériumok (például Pseudomonas aeruginosa) által kolonizált visszacsapódó vízcseppektől újra kontaminálódhat [31]. Ezért fontos, hogy a kézmosás után megtörténjen az alkoholos kézbedörzsölés is (kétfázisú kézfertőtlenítés).

Feltétlenül szükség van az alkoholos kézbedörzsölés előtt a kéztisztítás mechanikus eltávolító hatásának kihasználására a Clostridium difficile-fertőzött beteg ellátása után, mivel a fertőzést okozó baktérium spóráit nem képes elpusztítani az alkoholos kézfertőtlenítő szer [32].

\section{A védőkesztyú tökéletes védelmet nyújt a kóroko- zók terjesztése ellen? Szükséges-e egyáltalán kezet fertötleníteni a védőkesztyú felvétele előtt és a le- vétele után? A kesztyü viselésének élettartamát meghosszabbíthatjuk a lefertőtlenítésével vagy új- rafelvételével?}

A védőkesztyű használata védelmet nyújt az egészségügyi dolgozó számára a potenciális vérrel, váladékkal történő expozícióval szemben, valamint a beteg sérült 
bőrének vagy nyálkahártyájának érintése által létrejövő kontaminációval szemben [33]. A kesztyúhasználat befolyásolhatja a KC-t, mivel biztonságot nyújt, így két beteg között elmaradhat a kesztyú cseréje és könnyen létrejöhet egy keresztfertőzés [34, 35]. Egy átfogó tanulmány rávilágított arra, hogy gyakran a kesztyü viselete miatt elhagyták a kézhigiénét, továbbá előfordult az is, hogy szükségtelenül vették fel a védőeszközt, és a vizsgált esetek 37\%-ában a nem megfelelő kesztyúhasználat növelte a keresztfertőzés kialakulásának kockázatát [36]. Azt is gondolhatják a védőkesztyüt felvevők, hogy felesleges a kesztyüfelvétel előtti kézfertőtlenítés, hiszen úgyis befedi az egész kezüket a kesztyü. Rock és mtsai is megkérdőjelezik a védőkesztyü felvétele előtti kézfertőtlenítés indokoltságát. Mikrobiológiai mintavételezéssel vizsgálták a dolgozók kezét és a felvett kesztyúket úgy is, hogy a kesztyű felvétele előtt történt kézfertőtlenítés és úgyis, hogy kihagyták az előzetes kézfertőtlenítés lépését. Vizsgálatuk során a két csoport között nem találtak szignifikáns különbséget [37].

Ugyanakkor egy másik vizsgálat azt mutatta ki, hogy a több dolgozó által használt és a számukra központi helyre kirakott nyitott tetejü kesztyüsdobozban lévő, még használatlan kesztyúk is képesek kontaminálódni, ha fertőtlenítés nélküli kézzel nyúlnak hozzá a dolgozók (leggyakrabban Gram-pozitív baktériumok által) [38]. Ezek a kesztyứk a betegellátáskor már fertőzőforrásként jelenhetnek meg. Ezért a kesztyưk felvétele (már a dobozából való kivétele) előtt szükséges kezet fertőtleníteni. A védőkesztyű levétele közben könnyen kontaminálódhat a környezet [39], vagy akár a kesztyú viselőjének kézfeje, csuklója, alkarja is [40], sőt úgy is bekövetkezhet a kéz kontaminációja, hogy viselet közben megsérül (kiszakad) a kesztyú, vagy a kesztyű szárán át folyadék (vér, váladék, mosdatásnál használt víz stb.) csorog a kesztyú belsejébe. Ezért a védőkesztyű levétele után mindig kezet kell fertőtleníteni. A védőkesztyưkk fertőtlenítését és újrahasználatát a módszertani levelek egyértelmüen tiltják [41], egyedül a fejlődő országok számára engedélyezi a WHO [4], ahol igen szúkös a forrás.

Nagyon fontos tehát, hogy a dolgozók tudják és tudatosan alkalmazzák a helyes kesztyưhasználati indikációkat, mikor milyen típusú kesztyüt (steril kesztyű vagy védőkesztyú) kell viselni a különböző beavatkozásoknál, és tudják, hogy a kesztyú felvétele elött is és a levétele után is minden esetben el kell végezniük a kézfertőtlenítést $[4,42]$.

\section{Csak az egészségügyi személyzet kézhigiénés compliance-én múlik, hogy mennyire terjednek a betegellátó osztályokon a - kontakt úton (például kéz útján) továbbadható - fertózések?}

Néhány tanulmány rávilágított arra, hogy nemcsak az egészségügyi dolgozó keze játszhat szerepet a fertőzések tovaterjedésében, hanem a betegeké is [43-45]. A kezeken főként Gram-negatív baktériumokat [44, 45] és a Gram-pozitív baktériumok közül Staphylococcus aureus-t mutattak ki [43]. A kézhigiéné ötödik momentuma, azaz a beteg környezetének érintése után elvégzendő kézhigiéné ezért is fontos, mivel a beteg szervezetében és a bőrén lévő kórokozók többsége megtalálható a beteg zónájában, amely mintegy 1,5 méteres hatósugarú gömbként öleli körül a beteget. A beteg ugyanis az ágyában, illetve az ágya körül mozogva gyakran érinti a környezetében lévő élettelen felületeket, amelyeken a kórokozók hosszú ideig életképesek maradhatnak [46]. Mivel a betegzónában lévő berendezési tárgyak (például: ágyvég, éjjeliszekrény, kapaszkodók) felületeit nemcsak a beteg, hanem a betegellátók is rendszeresen érintik (például az ápolás során), a rajtuk lévő kórokozók könnyen kontaminálhatják a betegellátók kezét is.

Ezért a betegellátók kézhigiénés oktatásával párhuzamosan szükség van betegoktatásra is, amelyben ki kell térni a betegek jó kézhigiénéjének fontosságára is [47]. Mivel a betegzónába rendszeresen belépnek a betegekhez érkező látogatók is, az ő kezük is kontaminálódhat az itt élő kórokozókkal. Ezáltal potenciális fertőzőforrás lehet a látogató is. Birnbach és mtsai [48] intenzív osztályra érkező látogatók kezéről vettek mikrobiológiai mintát. A vizsgálatban a kézhigiénét végzőknél negatív volt az eredmény, míg azok esetében, akik nem végezték el a kéz megtisztítását, az összes mintából kórokozó tenyészett ki. A kitenyészett minták 26\%-ából 12 -féle patogén kórokozó is kimutatható volt. Ezek olyan kórokozók voltak, amelyek egészségügyi ellátással összefüggő fertőzéseket okozhatnak (többnyire Gram-negatív baktériumokat, de egy esetben meticillinrezisztens Staphylococcus aureus-t is találtak a látogató kezén).

A betegek és a látogatók KC-jének vizsgálata kényes kérdés, így a jelentősége ellenére kevés kutatás foglalkozott eddig vele, pedig már 1996-ban is megállapította egy tanulmány, hogy mindössze 7\%-ban végzik el a látogatók a szükséges kézhigiénét a beteg gyermek megérintése elött [49].

Egy későbbi vizsgálatban Randle és mtsai [50] már jobb eredményt kaptak. Az utóbbi vizsgálatban a betegek esetében 56\%-os, a látogatók esetében 57\%-os compliance-t figyeltek meg.

A betegellátók hatékony oktatásának módjáról létezik olyan elképzelés is, amelyben egyszerre történne a betegellátás két legfontosabb szereplőjének figyelemfelhívása a kézhigiéné súlyára, ugyanis a betegek bátorítása - arra, hogy emlékeztessék betegellátójukat, hogy fertőtlenítsék a kezüket, mielőtt hozzájuk érnek - növelheti az egészségügyi dolgozók KC-jét [51].

\section{Lehetséges-e müköröm, körömlakk viselete az egészségügyben dolgozók számára?}

A müköröm és hosszú köröm a védőkesztyư sérülését, kiszakadását okozhatja. A múköröm amellett, hogy elvékonyítja a természetes körmöket, a körömvég kemény felülethez való ütközése, koccantása hatására elválhat a megmaradt vékony körömlemeztől, és a keletkezett résbe szennyeződés vagy kézápoló krém juthat be, amit 
nem lehet onnan kitisztítani, így baktériumok és gombák is elszaporodhatnak ezeken a területeken [52].

Számos tanulmány szól arról, hogy epidemiológiai összefüggés van az egészségügyi dolgozók műkörme és a Gram-negatív kórokozók (főként Pseudomonas aeruginosa) és élesztőgombák által okozott infekciók, járványok között [53-55].

Egy 2000-ben publikált tanulmány az ápolók múkörme mellett felelősnek találta az ápolók hosszú természetes körmét is egy neonatalis intenzív centrumban kialakult, Pseudomonas aeruginosa okozta járványban [56]. A betegbiztonság és a dolgozói biztonság is azt kívánja, hogy az egészségügyi dolgozók, kiemelve a mütéti team tagjait, ne hordjanak múkörmöt, továbbá az ujjbegynél tovább érő körmöt se [57].

A körömlakkokkal kapcsolatban egyes tanulmányok azt találták, hogy nincs jelentős eltérés azon nővérek kezén lévő kórokozó-mennyiség között, akiknek lakkozott a körme, szemben azokéval, akiké nem lakkozott [57]. Ugyanakkor egy másik tanulmány szignifikáns különbséget közölt a lepattogzott lakkos körmú nővérek körmeinek kontamináltsága, a frissen festett körmű nővérek körme és azoknak a körme között, akik egyáltalán nem viseltek lakkot; a nem frissen lakkozott körmökön találták a legtöbb mikroorganizmust [58]. Az is figyelemre méltó, hogy a lakkozott körmök elfedhetik a köröm alá szorult szennyeződést, továbbá a körömlakkok többször használatosak és befertőződhet az egész üvegcse, főként, ha szépségszalonban használják, ahol több vendég körmére festik ugyanazt a lakkot. A lakkozott köröm és müköröm viseletét a betegellátásban mind a WHO [4], mind a Betegségellenőrzési és Megelőzési Központ (CDC) [59] megtiltja. Az Association of periOperative Registered Nurses (AORN) szervezet az újfajta lakkok (géllakk, shell-lakk) használatának mellőzésére is felszólítja az egészségügyi dolgozókat a rendelkezésre álló nagyon kevés evidencia és az akril műkörmök kémiai összetevőihez való hasonlósága miatt [60].

\section{A gyürü (például karikagyürü) viselete megen- gedhető a betegellátás során?}

A betegellátói munka közbeni gyưrûviseletet a dolgozók azzal magyarázzák, hogy nem akarják elveszíteni az ékszert, vagy rászorult az ujjukra és nem tudják levenni, vagy egyszerúen érzelmi okok (jegygyuurü) miatt mindig fent hagyják az ujjukon.

A szakirodalomban megjelenő tanulmányok szerint potenciális fertőzőforrás a gyưrü az egészségügyben munka közben $[61,62]$. Mivel a körmök, körömágyak megtisztítása nehéz, erre fókuszálunk a fertőtlenítőszeres kézbedörzsölés technikájának oktatása során. Ha gyưrüt is visel a dolgozó, akkor nála jóval több mikroorganizmusra (akár patogén kórokozóra) kell számítani, mintha ékszertelen lenne a keze. Hoffman és mtsai kimutatták, hogy a gyúrüs kezeken Enterobacter cloacae, Klebsiella pneumoniae, Acinetobacter calcoaceticus és Pseudomonas aeruginosa kórokozók lehetnek, illetve a tartós gyürühasználat olyan mértékű kontaminációhoz vezet, amely rutin kézhigiénével nem távolítható el [62]. Más tanulmányok is megerősítik, hogy jelentős mértékben kolonizálják a gyưrűs kezeket az Enterobacteriacae speciesek [63, 64], és egészségügyi ellátással összefüggő fertőzések kialakulásához vezethetnek. A gyưrü felülete alá szorult nedvesség például táptalajként szolgál a kórokozóknak, de az ékszer alá irritatív anyagok is beragadhatnak (például a púderes kesztyúboól) és a gyưrü levetése nélküli rutin kézmosás ellenére a gyưrü alatt továbbra is ott maradhatnak, és kontaktdermatitist okozhatnak. Továbbá a gyưrú átszakíthatja a kesztyưt, megszüntetve ezzel a barriert a kéz bőre és az éppen tapintott felületek, anyagok stb. között [65]. Mindezek mellett az egészségügy területén is okozhat munkahelyi balesetet a gyúrüviselet, ha például az ékszer beakad valamibe. Éppen ezért mind a WHO, mind pedig az OEK állásfoglalása az, hogy az egészségügyi dolgozók a betegellátás során ne viseljenek gyürüt $[4,6]$.

\section{Következtetés}

A betegellátás területén nélkülözhetetlen a helyes és megfelelő kézhigiéné. Törekedni kell arra, hogy a betegellátásban részt vevők minden szükséges helyen és esetben alkalmazzák a kézhigiénét, és hogy azt a legjobb gyakorlat szerint végezzék el. Jelen közlemény szerzői azzal a céllal gyưjtötték össze a kézhigiénével kapcsolatos leggyakoribb félreértéseket, hogy eloszlassák azokat, és megakadályozzák az említett tévhitek és rossz berögződések továbbterjedését a köztudatban. Az evidenciaalapú tudást oktatások és továbbképzések keretében szükséges ismertetni, mivel a tiszta kezek életet menthetnek.

Anyagi támogatás: A közlemény megírása anyagi támogatásban nem részesült.

Szerzői munkamegosztás: A szerzők egyenlő mértékben járultak hozzá a közlemény elkészítéséhez. A cikk végleges változatát mind a négy szerző elolvasta és jóváhagyta.

Érdekeltségek: A szerzőknek nincsenek érdekeltségeik.

\section{Irodalom}

[1] Allegranzi, B.: Report on the burden of endemic health care-associated infection worldwide. WHO Press, Geneva, 2011.

[2] Kilgore, M., Brossette, S.: Cost of bloodstream infections. Am. J. Infect. Control, 2008, 36(10), S172.el-S172.e3

[3] Sax, H., Allegranzi, B., Uçkay, I., et al.: 'My five moments for hand hygiene': a user-centred design approach to understand, train, monitor and report hand hygiene. J. Hosp. Infect., 2007, $67(1), 9-21$.

[4] WHO guidelines on hand hygiene in healthcare. WHO Press, Geneva, 2009.

[5] Allegranzi, B., Pittet, D.: Role of hand hygiene in healthcare-associated infection prevention. J. Hosp. Infect., 2009, 73(4), 305-315. 
[6] Milassin, M., Pechó, Z., Böröcz, K., et al.: Guideline of the National Center of Epidemiology on hand hygiene at health care and long-term care facilities [Az Országos Epidemiológiai Központ módszertani levele - A kézhigiéne gyakorlata az egészségügyi és az ápolást végző szociális szolgáltatásokban.] Epinfo, 2010, 17, 2. különszám, [Hungarian]

[7] Van de Mortel, T., Bourke, R., McLoughlin, J., et al.: Gender influences handwashing rates in the critical care unit. Am. J. Infect. Control, 2001, 29(6), 395-399.

[8] Creedon, S. A.: Healthcare workers' hand decontamination practices: compliance with recommended guidelines. J. Adv. Nurs., 2005, 51(3), 208-216

[9] Mahfouz, A. A., El Gamal, M. N., Al-Azraqi, T. A.: Hand hygiene non-compliance among intensive care unit health care workers in Aseer Central Hospital, south-western Saudi Arabia. Int. J. Infect. Dis., 2013, 17(9), e729-e732.

[10] Pittet, D., Hugonnet, S., Harbarth, S., et al.: Effectiveness of a hospital-wide programme to improve compliance with hand hygiene. Lancet, 2000, 356(9238), 1307-1312.

[11] Voss, A., Widmer, A. F.: No time for handwashing!? Handwashing versus alcoholic rub: can we afford $100 \%$ compliance? Infect. Control. Hosp. Epidemiol., 1997, 18(3), 205-208.

[12] Stutz, N., Becker, D., Jappe, U., et al.: Nurses' perceptions of the benefits and adverse effects of hand disinfection: alcohol-based hand rubs vs hygienic handwashing: a multicentre questionnaire study with additional patch testing by the German Contact Dermatitis Research Group. Br. J. Dermatol., 2009, 160(3), 565572 .

[13] Kramer, A., Hübner, N., Below, H., et al.: Improving adherence to surgical hand preparation. J. Hosp. Infect., 2008, 70(Suppl. 1), 35-43

[14] Jungbaner, F. H., Lensen, G. J., Groothoff, J. W., et al.: Exposure of the hands to wet work in nurses. Contact Dermatitis, 2004, $50(4), 225-229$.

[15] Cherry, N., Meyer, J. D., Adisesh, A., et al.: Surveillance of occupational skin disease: EPIDERM and OPRA. Br. J. Dermatol., 2000, 142(6), 1128-1134

[16] De Almeida e Borges, L. F., Silva, B. L., Gontijo Filho, P. P.: Hand washing: changes in the skin flora. Am. J. Infect. Control, 2007 $35(6), 417-420$.

[17] Larson, E. L., Hughes, C. A., Pyrek, J. D., et al.: Changes in bacterial flora associated with skin damage on hands of health care personnel. Am. J. Infect. Control, 1998, 26(5), 513-521.

[18] Kampf, G.: The six golden rules to improve compliance in hand hygiene. J. Hosp. Infect., 2004, 56(Suppl. 2), S3-S5.

[19] Brown, T. L., Gamon, S., Tester, P., et al.: Can alcohol-based hand-rub solutions cause you to lose your driver's license? Comperative cutaneous absorption of various alcohols. Antimicrob. Agents Chemother., 2007, 51(3), 1107-1108.

[20] Turner, P., Saeed, B., Kelsey, M. C.: Dermal absorption of isopropyl alcohol from a commercial hand rub: implications for its use in hand decontamination. J. Hosp. Infect., 2004, 56(4), 287290.

[21] Below, H., Partecke, I., Huebner, N. O., et al.: Dermal and pulmonary absorption of propan-1-ol and propan-2-ol from hand rubs. Am. J. Infect. Control, 2012, 40(3), 250-257.

[22] Kinnula, S., Tapiainen, T., Renko, M., et al:: Safety of alcohol hand gel use among children and personnel at a child day care center. Am. J. Infect. Control, 2009, 37(4), 318-321.

[23] Hormann, A. M., vom Saal, F. S., Nagel, S. C., et al.: Holding thermal receipt paper and eating food after using hand sanitizer results in high serum bioactive and urine total levels of bisphenol A (BPA). PLoS ONE, 2014, 9(10), el10509.

[24] Widmer, A. F.: Replace hand washing with use of a waterless alcohol hand rub? Clin. Infect. Dis., 2000, 31(1), 136-143.

[25] Pecho, Z., Milassin, M. (eds.): Update of disinfection - disinfection solutions in health care and epidemic. Disinfection Unit, Béla Johan National Center of Epidemiology [Tájékoztató a fertőtlenítésrôl - A betegellátásban és a járványügyi gyakorlatban alkalmazható fertőtlenítő eljárások. Johan Béla Országos Közegészségügyi Intézet Dezinfekciós Osztálya.] Franklin Nyomda és Kiadó Kft., Budapest, 1994. [Hungarian]

[26] Pecho, Z., Milassin, M. (eds.): Update of disinfection - disinfection solutions in health care and epidemic. Disinfection Unit, Béla Johan National Center of Epidemiology [Tájékoztató a fertőtlenítésről - A betegellátásban és a járványügyi gyakorlatban alkalmazható fertőtlenítő eljárások. Johan Béla Országos Epidemiológiai Központ Dezinfekciós Osztálya.] Nyomdaipari Szolgáltató Kkt., Budapest, 2000. [Hungarian]

[27] Pecho, Z., Milassin, M. (eds.): Update of disinfection - disinfection solutions in health care and epidemic. Disinfection Unit, National Center of Epidemiology [Tájékoztató a fertőtlenítésről - A járványügyi gyakorlatban és az egészségügyi szolgáltatásban alkalmazható fertőtlenítő eljárások kézikönyve. Országos Epidemiológiai Központ Dezinfekciós Osztálya.] Dursusz Bt., Budapest, 2007. [Hungarian]

[28] Pecho, Z., Milassin, M. (eds.): Update of disinfection - disinfection solutions in health care and epidemic. Disinfection Unit, National Center of Epidemiology [Tájékoztató a fertőtlenítésrôl - A járványügyi gyakorlatban és az egészségügyi szolgáltatásban alkalmazható fertőtlenítő eljárások kézikönyve. Országos Epidemiológiai Központ Dezinfekciós Osztálya.] Dursusz Bt., Budapest, 2012. [Hungarian]

[29] Vanyolos, E., Peto, K., Viszlai, A., et al.: Usage of ultraviolet test method for monitoring the efficacy of surgical hand rub technique among medical students. J. Surg. Educ., 2015, 72(3), $530-535$.

[30] Rotter, M. L.: Hand washing and hand disinfection. In: Mayhall, C. G. (ed.): Hospital epidemiology and infection control. 2nd ed. Williams \& Wilkins, Baltimore, 1999, 1339-1355.

[31] Trampuz, A., Widmer, A. F.: Hand hygiene: a frequently missed lifesaving opportunity during patient care. Mayo Clin. Proc., 2004, 79(1), 109-116.

[32] Böröcz, K., Gacs, M., Hajdu, Á., et al.: Guideline of National Center of Epidemiology, Professional Association of Medical Microbiology and Professional Association of Infectology. Diagnostics, therapy and prevention of Clostridium difficile infection. [Az Országos Epidemiológiai Központ, az Orvosi Mikrobiológiai Szakmai Kollégium és az Infektológiai Szakmai Kollégium módszertani levele. A Clostridium difficile fertőzések diagnosztikájáról, terápiájáról és megelőzéséről.] Epinfo, 2011, 18, 4. különszám. [Hungarian]

[33] Goldmann, D. A.: The role of barrier precautions in infection control. J. Hosp. Infect., 1991, 18(Suppl.), A515-A523.

[34] Girou, E., Chai, S. H., Oppein, F., et al.: Misuse of gloves: the foundation for poor compliance with hand hygiene and potential for microbial transmission. J. Hosp. Infect., 2004, 57(2), 162169.

[35] Pan, A., Mondello, P., Posfay-Barbe, K., et al.: Hand hygiene and glove use behavior in an Italian hospital. Infect. Control Hosp. Epidemiol., 2007, 28(9), 1099-1102.

[36] Loveday, H. P., Lynam, S., Singleton, J., et al.: Clinical glove use: healthcare workers' actions and perceptions. J. Hosp. Infect., 2014, 86(2), 110-116.

[37] Rock, C., Harris, A. D., Reich, N. G., et al.: Is hand hygiene before putting on nonsterile gloves in the intensive care unit a waste of health care worker time? - a randomized controlled trial. Am. J. Infect. Control, 2013, 41(11), 994-996.

[38] Rossoff, L. J., Lam, S., Hilton, E, et al.: Is the use of boxed gloves in an intensive care unit safe? Am. J. Med., 1993, 94(6), 602607.

[39] Lai, J. Y., Guo, Y. P., Or, P. P., et al.: Comparison of hand contamination rates and environmental contamination levels between two different glove removal methods and distances. Am. J. Infect. Control, 2011, 39(2), 104-111. 
[40] Zamora, J. E., Murdoch, J., Simchison, B., et al.: Contamination: a comparison of 2 personal protective systems. CMAJ, 2006, 175(3), 249-254.

[41] Siegel, J. D., Rhinehart, E., Jackson, M., et al.: 2007 guideline for isolation precautions: preventing transmission of infectious agents in healthcare settings. Am. J. Infect. Control, 2007, 35(10 Suppl. 2), S65-S164.

[42] Doebbeling, B. N., Pfaller, M. A., Houston, A. K., et al.: Removal of nosocomial pathogens from the contaminated glove. Implications for glove reuse and handwashing. Ann. Intern. Med., 1988, 109(5), 394-398.

[43] Larson, E. L., Cronquist, A. B., Whittier, S., et al.: Differences in skin flora between inpatients and chronically ill outpatients. Heart Lung, 2000, 29(4), 298-305.

[44] Sanderson, P. J., Weissler, S.: Recovery of coliforms from the hands of nurses and patients: activities leading to contamination. J. Hosp. Infect., 1992, 21(2), 85-93.

[45] Istenes, N., Bingham, J., Hazelett, S., et al.: Patients' potential role in the transmission of health care-associated infections: prevalence of contamination with bacterial pathogens and patient attitudes toward hand hygiene. Am. J. Infect. Control, 2013, $41(9), 793-798$.

[46] Kramer, A., Schwebke, I., Kampf, G.: How long do nosocomial pathogens persist on inanimate surfaces? A systematic review. BMC Infect. Dis., 2006, 6, 130 .

[47] Nagy, K., Szél, B.: Improving hand hygiene compliance at the University of Szeged. [Kézhigiénés compliance fejlesztése a Szegedi Tudományegyetemen.] Népegészségügy, 2013, 91(4), 274-281. [Hungarian]

[48] Birnbach, D. J., Rosen, L. F., Fitzpatrick, M., et al.: An evaluation of hand hygiene in an intensive care unit: Are visitors a potential vector for pathogens? J. Infect. Public Health, 2015, 8(6), 570574.

[49] Brown, J., Froese-Fretz, A., Luckey, D., et al.: High rate of hand contamination and low rate of hand washing before infant contact in a neonatal intensive care unit. Pediatr. Infect. Dis. J., 1996, 15(10), 908-910.

[50] Randle, J., Arthur, A., Vaughan, N.: Twenty-four-hour observational study of hospital hand hygiene compliance. J. Hosp. Infect., 2010, 76(3), 252-255.

[51] Davis, R., Parand, A., Pinto, A., et al.: Systematic review of the effectiveness of strategies to encourage patients to remind healthcare professionals about their hand hygiene. J. Hosp. Infect., $2015,89(3), 141-162$.

[52] Sullivan, E. E.: Off with her nails. J. Perianesth. Nurs., 2003, $18(6), 417-418$.
[53] McNeil, S. A., Foster, C. L., Hedderwick, S. A., et al.: Effect of hand cleansing with antimicrobial soap or alcohol-based gel on microbial colonization of artificial fingernails worn by health care workers. Clin. Infect. Dis., 2001, 32(3), 367-372.

[54] Pottinger, J., Burns, S., Manske, C.: Bacterial carriage by artificial versus natural nails. Am. J. Infect. Control, 1989, 17(6), 340344.

[55] Rubin, D. M.: Prosthetic fingernails in the OR. AORN J., 1988, 47(4), 944-948.

[56] Moolenaar, R. L., Crutcher, J. M., San Joaquin, V. H., et al.: A prolonged outbreak of Pseudomonas aeruginosa in a neonatal intensive care unit: did staff fingernails play a role in disease transmission? Infect. Control Hosp. Epidemiol., 2000, 21(2), 80-85.

[57] Edel, E., Houston, S., Kennedy, V., et al.: Impact of a 5-minute scrub on the microbial flora found on artificial, polished, or natural fingernails of operating room personnel. Nurs. Res., 1998, $47(1), 54-59$.

[58] Wynd, C. A., Samstag, D. E., Lapp, A. M.: Bacterial carriage on the fingernails of OR nurses. AORN J., 1994, 60(5), 799-805.

[59] Centers for Disease Control and Prevention: guideline for hand hygiene in health-care settings: recommendations of the Healthcare Infection Control Practices Advisory Committee and the HICPAC/SHEA/APIC/IDSA Hand Hygiene Task Force. MMWR, 2002, 51(RR-16), 1-45.

[60] Wood, A., Van Wicklin, S. A.: Clinical Issues - June 2015. AORN J., 2015, 101(6), 701-708.

[61] Field, E. A., McGowan, P., Pearce, P. K., et al.: Rings and watches: should they be removed prior to operative dental procedures? J. Dent., 1996, 24(1-2), 65-69.

[62] Hoffman, P. N., Cooke, E. M., McCarville, M. R., et al.: Microorganisms isolated from skin under wedding rings worn by hospital staff. Br. Med. J., 1985, 290(6463), 203-207.

[63] Fagernes, M., Lingaas, E.: Factors interfering with the microflora on hands: a regression analysis of samples from 465 healthcare workers. J. Adv. Nurs., 2010, 67(2), 297-307.

[64] Fagernes, M., Lingaas, E., Bjark, P.: Impact of a single plain finger ring on the bacterial load on the hands of healthcare workers. Infect. Control Hosp. Epidemiol., 2007, 28(10), 1191-1195.

[65] Nicolai, P., Aldam, C. H., Allen, P. W.: Increased awareness of glove perforation in major joint replacement. J. Bone Joint Surg. Br., 1997, 79(3), 371-373.

(Szél Borbála,

Szeged, Tisza L. krt. 107., 6724 e-mail: szelbo@gmail.com)

\section{ÁLLÁSAJÁNLAT}

Cégünk, a Plazmacentrum Kft., budapesti munkahelyre keres transzfuziológus orvost. Feladata egy most nyíló plazmaferezis állomás feladatainak ellátása mellékállásban. Kiemelt bérezés megegyezés szerint.

Jelentkezni a abela@plazmacentrum.hu e-mail címre küldött önéletrajzzal és fizetési igény megjelöléssel lehet. További információ Árvavölgyi Béla ügyvezetőnél.

Tel: 06209509050

E-mail: abela@plazmacentrum.hu 